\title{
Adaptation Strategies of Migrant Workers from Ukraine during the COVID-19 Pandemic
}

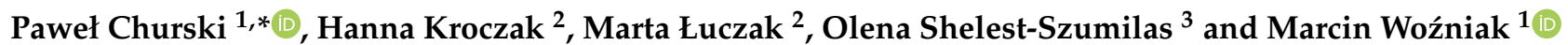 \\ 1 Faculty of Human Geography and Planning, Adam Mickiewicz University in Poznań, \\ 61-712 Poznań, Poland; woz@amu.edu.pl \\ 2 Observatory of Economy and Labour Market of the Poznan Agglomeration, 61-727 Poznań, Poland; \\ h.kroczak@cdzdm.pl (H.K.); m.luczak@cdzdm.pl (M.Ł.) \\ 3 Department of Education and Personnel Development, Institute of Socio-Economics, Poznań University of \\ Economics and Business, 61-875 Poznań, Poland; olena.shelest-szumilas@ue.poznan.pl \\ * Correspondence: chur@amu.edu.pl
}

check for updates

Citation: Churski, P.; Kroczak, H.; Łuczak, M.; Shelest-Szumilas, O.; Woźniak, M. Adaptation Strategies of Migrant Workers from Ukraine during the COVID-19 Pandemic. Sustainability 2021, 13, 8337. https://doi.org/10.3390/su13158337

\section{Academic Editors: Juan}

Carlos Rodríguez Cohard and

Antonio Vázquez Barquero

Received: 16 May 2021

Accepted: 20 July 2021

Published: 26 July 2021

Publisher's Note: MDPI stays neutral with regard to jurisdictional claims in published maps and institutional affiliations.

Copyright: (c) 2021 by the authors. Licensee MDPI, Basel, Switzerland. This article is an open access article distributed under the terms and conditions of the Creative Commons Attribution (CC BY) license (https:// creativecommons.org/licenses/by/ $4.0 /)$.

\begin{abstract}
The COVID-19 pandemic has had far-reaching social and economic consequences. They are visible particularly in the functioning of local labour markets, affecting less privileged groups such as migrant workers, in a specific way. Here, our analysis aims to identify the strategies of adaptation of Ukrainian economic migrants to the changing situation in the local labour market in the Poznan agglomeration during the COVID-19 pandemic. The analysis relies on the results from quantitative research on changes in the demand for labour and adjustment of competence of immigrants to the Poznań agglomeration labour market throughout the pandemic and in the perspective of the nearest future, as well as on qualitative research conducted using the IDI (in-depth interviews) technique, carried out via the purposive sampling of 30 economically active Ukrainian migrant workers. The identified adaptation strategies are organised according to the assumptions of Pierre Bourdieu's concept of capital(s). The capital of the researched group with respect to the labour market is treated as both the potential and resources the immigrants offer, produce, apply, and mutually convert in the implementation of their own adaptation strategies to the changing situation of the labour market. We extracted eight types of migrant adaptation strategies with respect to the labour market. These strategies differ in terms of objectives, resources, time perspectives, and other factors considered to be important from migrants' perspectives. On the basis of interviews, we were able to assess the robustness of these strategies in view of economic shocks and identify the process of capital conversion and exchange.
\end{abstract}

Keywords: local labour market; migrant workers; Pierre Bourdieu's capital(s); adaptation strategies; COVID-19; Poznań agglomeration; Poland

\section{Introduction}

The COVID-19 pandemic has resulted in a global health crisis which has quickly led to economic shocks, including those affecting the labour market. This, in turn, has brought about an unprecedented global job crisis [1]. Successive waves of the pandemic, and the serious economic and social challenges they have entailed, have made it difficult to forecast future development trajectories [2,3]. In these circumstances, what becomes especially crucial is the monitoring of the changes occurring in the labour market. Consequences of this new situation in the labour market are subject to analysis in many countries [4-6]. What is important is that from its onset, the pandemic's economic and social effects have been characterized by definite social segmentation and spatial variation, which has also been observed in the labour market [7-9]. In particular, this situation adversely affects migrant workers [10], who belong to less privileged groups in the world of work [11] and have found themselves in a precarious position in the conditions of the COVID-19 pandemic [12]. In the Polish labour market, the most important place in this group is occupied by economic 
migrants from Ukraine who, until the outbreak of the pandemic and the first lockdowns, ensured the sustainability of the job market which was affected by significant shortages of supply $[13,14]$. In this new situation, this group has become particularly vulnerable to the consequences of changes in the functioning of the labour market due to the conditions of COVID-19 [15]. The tendencies observed may, on the one hand, lead to a rapid increase in economic poverty which will entail numerous negative social implications [16]. On the other hand, changes taking place in work organization and the universalisation of remote work open up new possibilities which can transform the future volume and structure of labour supply and demand [17]. In this situation, migrants' skills in regards to the way in which they use their capitals in the process of developing strategies of adaptation to the dynamically-changing job market is of particular importance [18-20].

The primary aim of the analysis is to identify the influence of the COVID-19 pandemic on the situation of migrant workers from Ukraine in the Poznan agglomeration. The main objectives, based on specific research questions, are as follows:

1. What quantitative and structural changes have affected migrant workers from Ukraine in the local labour market with respect to national and European trends resulting from the impact of the COVID-19 pandemic?

2. How has the migrants' labour demand changed in the local labour market during the pandemic?

3. What are the predictions in terms of changes in labour demand for Ukrainian migrant workers over the next three years?

4. What are migrant workers' strategies of adaptation to the changes in the labour market under the conditions of the COVID-19 pandemic?

5. What capitals do Ukrainian migrant workers have, how do they produce, apply, and mutually convert them in the process of implementation of adaptation strategies under the conditions of the COVID-19 pandemic?

To answer the research questions, a qualitative study was conducted. The results discussed in this article are based on 30 in-depth interviews with Ukrainian citizens who were economically active in the local labour market of the Poznań agglomeration.

We take note of the dynamic approach in the investigation. The results refer to three periods: the situation before the COVID-19 pandemic (from the immigrants' arrival in Poland to March 2020), during the pandemic (March 2020-March 2021), and the nearest future (plans for the maximum next three years). The geographical range of the research included the Poznań agglomeration understood as the city of Poznań and 17 communes of the Poznań county (PL powiat), which form the Poznań agglomeration [21]: Buk, Czerwonak, Dopiewo, Kleszczewo, Komorniki, Kostrzyn, Kórnik, Luboń, Mosina, Murowana Goślina, Pobiedziska, Puszczykowo, Rokietnica, Stęszew, Suchy Las, Swarzędz and Tarnowo Podgórne (Figure 1).

In 2019, the population of the Poznan agglomeration was 1,050,383 inhabitants, including 552,901 people aged 18 to 65 . A precise overview of the situation in the local labour market is presented in Figure 2, showing the changes in the unemployment rate over 2019-2020. On average, in January 2019, higher rates were observed than in January 2020. The last month of 2019 was characterized by a record-low unemployment rate (1.1\%), accompanied by a high job vacancy rate $(1 \%)$. The situation began to change with the spread of the COVID-19 pandemic at the end of the first quarter of 2020. The lockdown introduced in March forced the closure of many companies, and the epidemiological restrictions had an impact on both employment level and labour demand. As a result, since the beginning of the second quarter of 2020, the unemployment rate in the agglomeration began to rise. Despite this, the rate still reaches the lowest values among Polish cities-in December 2020, and the unemployment rate for the agglomeration was $2.1 \%$. At the beginning of 2021, the rate was still subject to a small, but steady increase (2.2\% in April). At the same time, unemployment in Poland reached $6.2 \%$, which was still below the $8.1 \%$ average for the Euro zone. It is also worth noting that with the beginning of 2021, the vacancy rate also increased, reaching $0.71 \%$ in January (i.e., the highest value since September 2018). This 
may suggest a slight recovery on the labour demand side, but further forecasting of the labour market situation should be considered highly uncertain due to the third wave of the pandemic and the epidemiological restrictions which are still in place (May 2021).

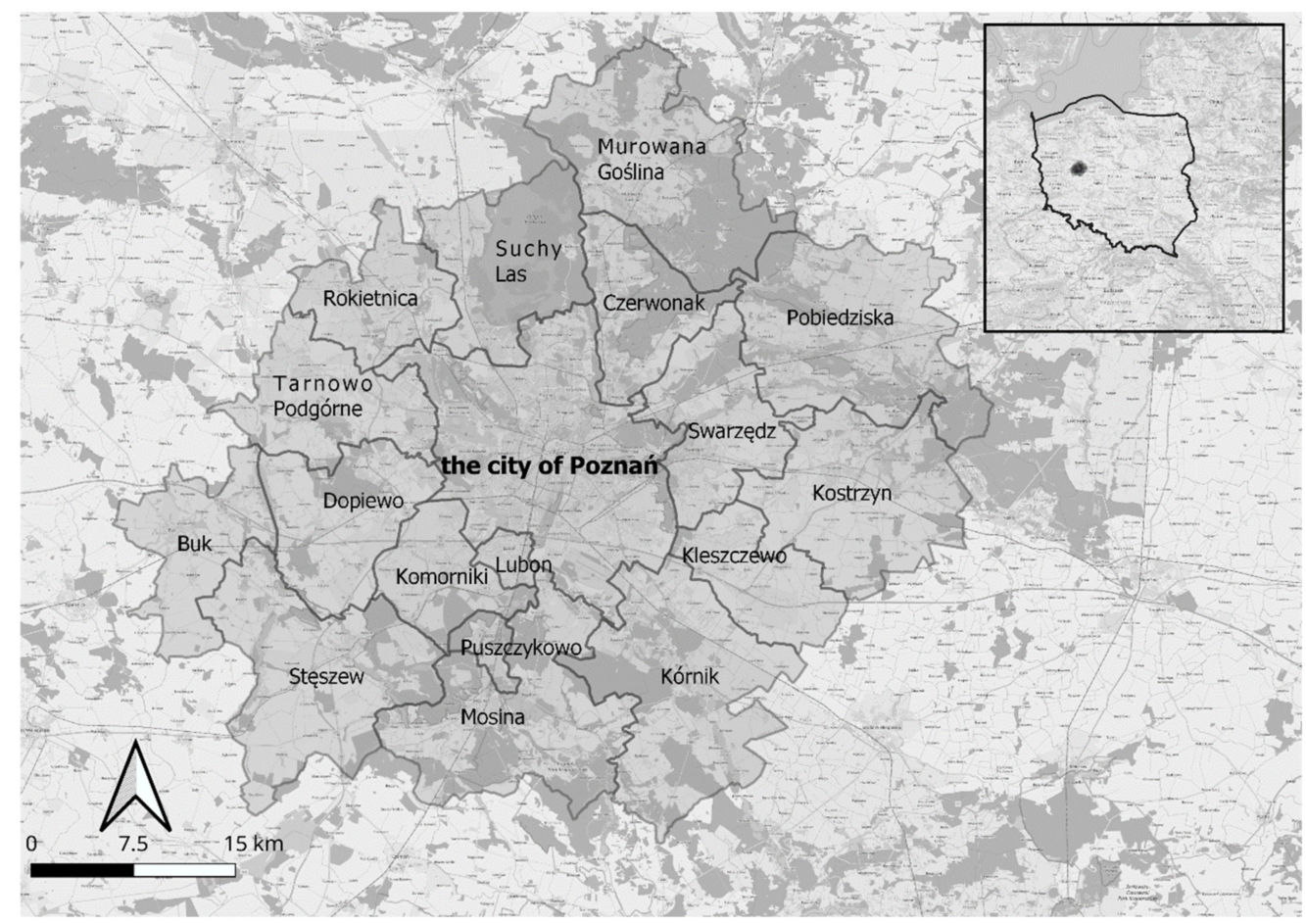

Figure 1. The Poznań agglomeration in the administrative structure of the Wielkopolskie voivodeship and Poland. Source: Own elaboration.

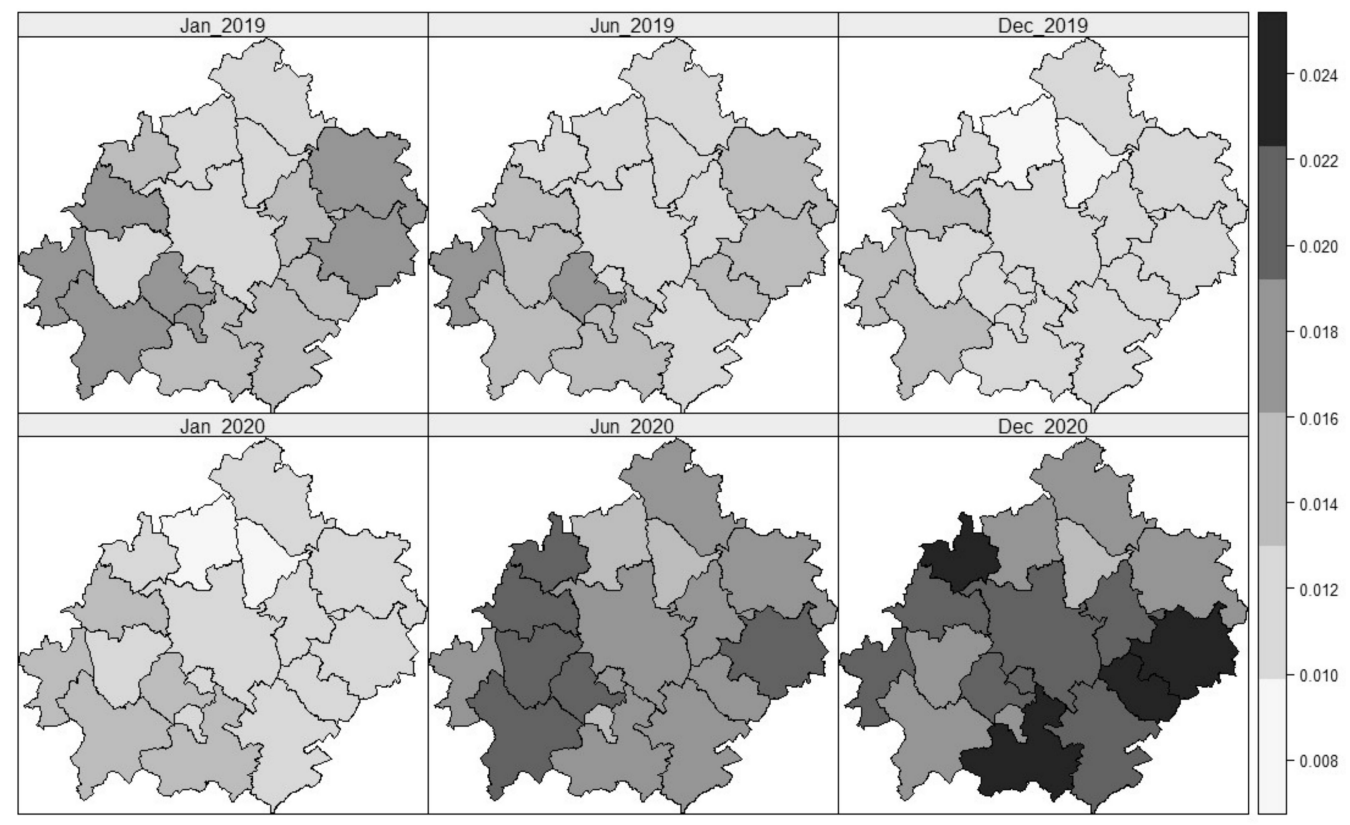

Figure 2. Unemployment rate in the Poznan agglomeration in 2019 and 2020. Source: Own elaboration.

However, the situation of migrant workers seems to be less favourable if compared to natives. The fact is underlined in the extensive literature on the subject. [7] points out that working conditions are important factors diversifying migrant employment. [16] also stress the discrepancies in factors such as the type of job contract or wages between home 
country and foreign workers which can lead to a worse situation for migrant workers in the labour market.

Recent analyses confirm the significant contribution of foreign workers to the functioning and development of Polish enterprises. According to the assessment of the National Bank of Poland, migrant workers from Ukraine contributed to about $13 \%$ of the total GDP growth in 2013-2018 [22]. The importance of hiring foreigners to sustain business is also recognized by employers. According to [23], more than 2/3 of the surveyed employers assess the impact of migrant workers on the development of the Polish economy as beneficial. Migrant workers in Poland occupy not only low-skilled but also specialists' positions as pointed out by [24].

In the case of migrant workers from Ukraine, for whom Russia had traditionally been the main destination country, the change in the direction of migration is the result of the armed conflict in the east of the country [25]. The Statistical Office of Ukraine reports that in 2015-2017, the majority of migrant workers chose Poland to pursue their professional goals [6]. Key factors attracting Ukrainians' migration to Poland are not only higher wages and much lower corruption, but also several demographic and socio-cultural aspects including territorial and linguistic proximity, relatively easy access to employment, availability of higher education, and family ties [26]. The migration activity of Ukrainians is also affected by demographic situation, life expectancy, public health status, upbringing of the young generation, and family atmosphere [27].

The situation related to the outbreak of the pandemic and subsequent economic lockdown, which took place in March 2020, did not particularly affect the total number of residence permits issued to foreigners (Figure 3). Moreover, it should be noted that the number of permits increased in the three provinces which were most frequently chosen by foreigners as their destination (this includes the Wielkopolskie voivodeship). At the same time, however, in the majority of the less popular regions, the number of residence permits issued to foreigners decreased. This suggests that the COVID-19 pandemic shock affected the Polish territory unevenly. Wealth regions with strong economies and good labour market performance (e.g., Mazowieckie, Małopolskie, Wielkopolskie) suffered much less than the economically-weaker regions (e.g., Lubelskie, Warmińsko-Mazurskie, Podkarpackie), where the demand for the foreign labour force significantly decreased. In this situation, citizens of Ukraine comprise the largest share of migrants in the Poznan agglomeration (In 2020 a temporary residence permit was issued to 18,157 non-Polish citizens in Wielkopolskie voivodship, 16,495 of whom (90.85\%) were migrants from Ukraine [migracje.gov.pl, accessed on 14 April 2021]).

The data on residence permits do not fully reflect the real number of foreigners residing in Poland. The information on migrant inflows is collected by numerous institutions and is therefore scattered. However, the Central Statistical Office estimated that at the end of 2019 there were more than 2106 thousand foreigners residing in Poland, including over 1351 thousand citizens of Ukraine [28].

The article is organised in the following way. In the Section 1, we explain the choice of the research aim, define the primary and specific objectives, determine the spatial and temporal scope of the analysis, characterize the situation in the labour market in Poland and in the Poznan agglomeration (with particular emphasis on the position of migrant workers), and present the structure of the article. In the Section 2, we demonstrate the theoretical background, focusing on the definition of the strategy of adaptation of migrant workers to the changes in the labour market resulting from the economic consequences of the COVID-19 pandemic using Pierre Bourdieu's theory of capitals for the identification and typology of these strategies. Then, we define the scope of the used data and the applied research methods. The most important outcomes are presented in the Section 4. The first step includes the opinions of employers regarding the changes in the demand for immigrant work during the COVID-19 pandemic. In the second step, we show the results of interviews with migrant workers from Ukraine. We provide the typology of the adaptation strategies with respect to the pandemic. Subsequently, we show and explain 
the processes of capital conversion which allow migrants to achieve their strategic goals on the local labour market. Finally, the most important results are critically analysed using the body of source literature. The article ends with our Conclusions.

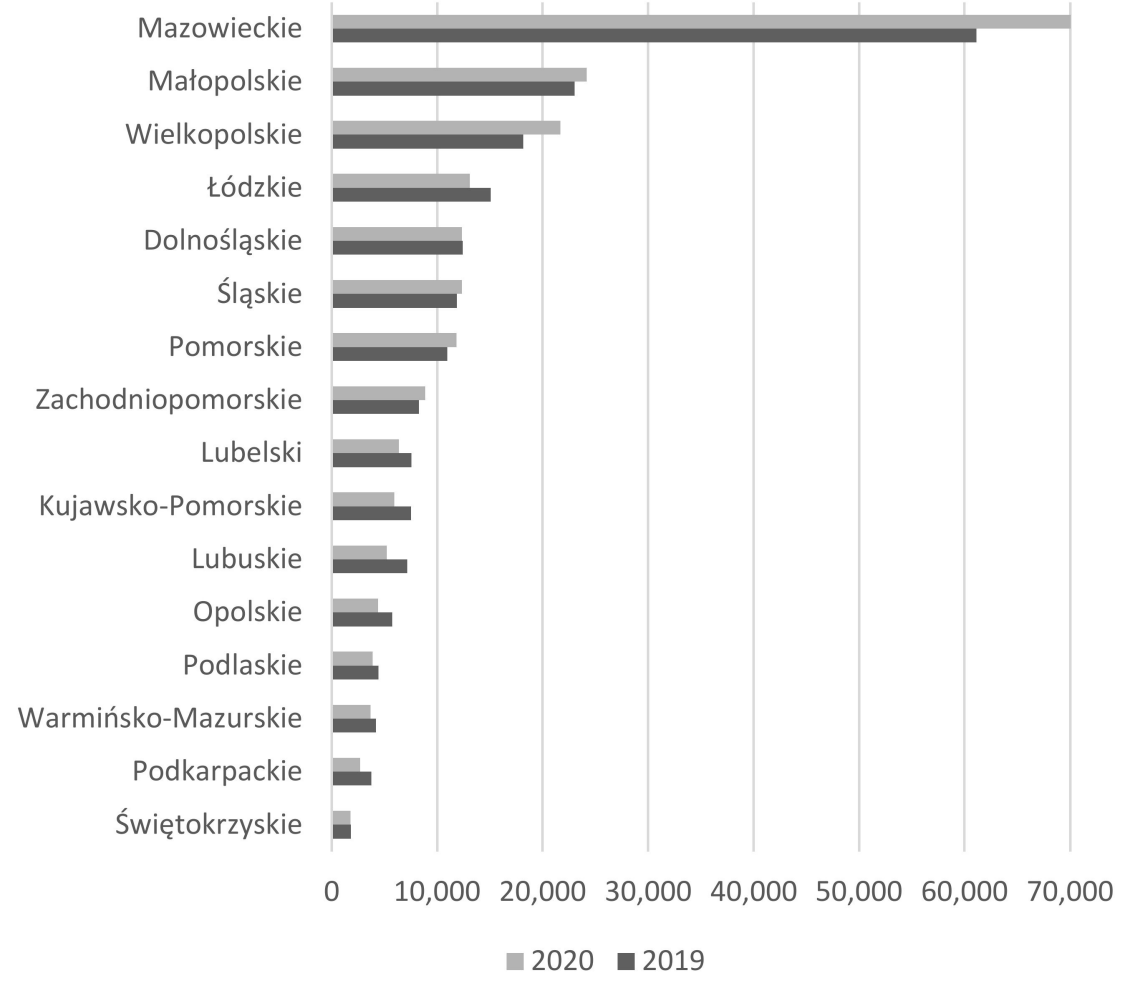

Figure 3. The number of residence permits issued to migrants in the Polish regions in 2019 and 2020. Source: Own elaborations.

\section{Theoretical Background}

We looked at the individual stories of migrant workers from the perspective of wellknown theory of capital and class distinction [29-31]. In Bourdieu's theory, the key element is the term capital. Everyone owns capital, which can be understood as assets. These assets can be productively used, exchanged, and multiplied in everyday life. The key term that we use to explain how these processes continue is capital conversion, which refers to transforming one type of capital into another. This transformation depends on current circumstances (including one's determination to activate each available capital) and what individual needs occur in one's life at the present moment. Conversion of migrant's assets is a crucial part of their adaptation to the conditions in a host country. According to the literature, it turns out that migrants use different strategies of capital conversion, depending on the destination country [30-34].

Bourdieu distinguished four general types of capital: symbolic, economic, cultural, and social. We assume that each migrant worker possesses these assets and uses them to achieve certain goals. From that perspective, symbolic capital reflects the immigrant's place in the social structure (relations of power and subordination) of the host country. It can be perceived as the potential which an immigrant has to become a (meaningful) social actor in the host country. This potential determines his/her competences and possibilities and thus impacts his/her chances of success in socio-economic life, including participation in the labour market. The term 'economic capital' usually refers to goods such as money and other tangible assets (e.g., a car, a flat) which an immigrant owns (or has in his/her possession) and uses to function and gain life stability, but they can also be 'exchanged' for other assets (e.g., qualifications, social position, relationships). By 'cultural capital', we mean all the features, knowledge, and skills which enable an immigrant to operate in specific functional structures in the host country (e.g., social, institutional, labour market). The 
fourth type is 'social capital', which consists of a network of the immigrant's relationships (and acquaintances) that can afford him/her efficient functioning in the host community. An important part of one's social capital is the fact of belonging to various groups and forming a network of permanent relationships.

The concept of adaptation strategy is used in Polish research on migration, both in relation to Poles staying abroad and to foreigners living in Poland. The term is usually understood in a wider context, for example as 'becoming a member of a new community' and then surviving under specific circumstances such as an economic crisis [35-37], It has also been adapted to migration research by e.g., [20]. Therefore, it is partly related to the functioning of migrant workers in the labour market of the host country, but there is no adequate definition that we could apply in our research. On the basis of strategy definitions available in dictionaries and Bourdieu's capital theory, in this study we formulate the following definition of the migrant workers' strategy of adaptation to the labour market. We understand it as a more or less complex and conscious plan of immigrant's action aimed at realizing and achieving certain goals by using his/her own capital in view of employers' expectations, opportunities, and limitations in the labour market of the Poznan agglomeration.

On a basis of the definition given above, we developed five criteria by which we were able to distinguish the following eight types of strategies. These criteria are presented in Table 1, which was then used to extract adaptation strategies and their vulnerability in terms of the pandemic.

Table 1. Criteria for distinguishing the adaptation strategies.

\begin{tabular}{cc}
\hline Criterion & The Scale of Classification \\
\hline Objectives & From strictly specified to entirely unspecified \\
\hline Resources & $\begin{array}{c}\text { Assets diversification (different kinds of } \\
\text { economic, social, cultural and symbolic assets); } \\
\text { level of capital (from negative to high) }\end{array}$ \\
\hline Time perspective & $\begin{array}{c}\text { From short-term (up to one year) to } \\
\text { medium-term perspective (up to three years) }\end{array}$ \\
\hline $\begin{array}{c}\text { Other specific factors important from } \\
\text { migrant's perspective }\end{array}$ & $\begin{array}{c}\text { Opportunities and limitations on the local } \\
\text { labour market }\end{array}$ \\
\hline Impact of the COVID-19 pandemic & From very low to very high \\
\hline Source: Own elaborations.
\end{tabular}

Although we are aware of the multiplicity of perspectives used in the analysis of migration, we have decided to apply the whole Bourdieu's capital concept (including four basic types of capital distinction) as, to the best of our knowledge, no such empirical work has been done in the migration research before. We found it the most complex "touchstone" that can be used to identify important assets of migrant workers on the labour market.

\section{Materials and Methods}

We decided to use methods triangulation and to combine both quantitative and qualitative research techniques. This enabled us to get a deeper insight in the context of the COVID-19 pandemic and to detect both employers' and employees' perspectives.

\subsection{Quantitative Research}

We started by looking at the employers' perspective and employed the survey data collected from October to December 2020. The data collection was undertaken by computerassisted telephone (CATI) and web interviews (CAWI). CAWI questionnaires were sent to respondents who could not be reached by phone or refused to give a telephone interview.

As part of the pilot study, ten interviews were carried out to verify the research assumptions and evaluate the content of the questions. After pretesting the questionnaire, 
minor modifications were made to the question sequence and content. The final version of the questionnaire consisted of 37 questions and covered five subject areas: reasons and barriers of hiring migrant workers, the impact of COVID-19 pandemic on employment, employers' perceptions of migrants' knowledge and skills in relation to the requirements of the most prevalent jobs, employers' support for migrant workers, and plans regarding hiring migrant workers and local employment policy.

The data was collected on a sample of 420 employers from the Poznan agglomeration. The originally-planned research sample could not be accomplished because of the difficulties in reaching respondents due to remote work.

\subsection{Qualitative Research}

The data for the qualitative analysis was collected using in-depth interviews (IDI) on a sample of 30 respondents. Respondents were reached using respondent-driven sampling technique. At the first stage of the data collection, interviewers selected several members of the target population (the so-called "seeds"). Next, each respondent was interviewed and asked to recruit one to two respondents. Interviewees were Ukrainian citizens who have resided in Poland at least since March 2019 (12 months before the first lockdown restrictions in Poland were implemented) and had legal employment or were looking for a job in the Poznań agglomeration. The selection of respondents was based on two additional criteria which took into account the migrant labour market statistics for the Poznan agglomeration (i.e., the sector of employment and sociodemographic characteristics) [14,38]. Our focus was on the respondents who were employed in sectors with the highest share of migrant workers. (According to the statistics published by the Polish Ministry of Development, Labour and Technology, in 2020 the majority of work permits were issued for migrant workers employed in the following industries: activities in the field of administrative and support services activities (22.12\%), construction $(23.52 \%)$, manufacturing (23.34\%), transport and storage (17.83\%) [39]. Not all of these sectors have been exposed to the COVID-19 pandemic impact in the same way. Among sectors where the majority of migrant workers concentrate, the deepest fall in overall employment was reported in such industries as administrative and support service activities, agriculture, forestry and fishing, manufacturing, and accommodation and food services [40]. Because of seasonal character of farming and agricultural work, our study did not cover migrants employed in agriculture, forestry and fishing. In our research the focus was on both the sectors which have been most affected by the COVID-19 and those where the pandemic effects have not been so noticeable). Interviewees were also selected based on their educational degree, age, and gender. It should be emphasised that the gender criterion was not consistent with the statistics. To achieve the best diversification of social networks, the rule of "one respondent from one household" was applied.

The majority $(86.67 \%)$ of the participants were under 40 , and the share of male and female participants was equal. Most respondents were employed in construction (23.33\%), the others had jobs in such sectors as accommodation and food services $(20 \%)$, transport and storage $(13.33 \%)$, trade $(13.33 \%)$, manufacturing $(10 \%)$, and other sectors (mostly services, 20\%). As many as 13 individuals (43.33\%) had higher education, while the others (17 respondents) had vocational or secondary education $(56.67 \%)$.

The IDI questions were semi-structured. The interview scenario was divided into two parts. At the beginning, an interviewee was asked to write key points regarding his/her professional and life situation on a timeline. When an interviewee was ready to talk, the interviewer started the proper conversation. An interview was focused on respondents' career goals and several types of capitals used to achieve them. Each section referred to the past (what the situation looked like from their arrival to Poland to the outbreak of the pandemic in March 2020), the present (what it is like in times of the pandemic), and the near future (how it will be in the nearest future; interviewees decided what the nearest future meant for them, if the time span was needed to be precise, the interviewer asked about maximum three years). In the last part of the interview, a respondent was asked about 
significant changes in employers' expectations caused by the pandemic crisis, the sense of job security and opportunities to achieve his/her career goals. The interview scenario was slightly modified after the pilot study. It was available in three versions (Polish, Russian and Ukrainian) and was checked in terms of its cultural context.

Interviews were conducted from February to March 2021. Since they were fluent in Polish, the interviewers could communicate with the authors of the study and could understand the concept of the research well. The induction training and feedback sessions for interviewers were provided by the authors of the study. Interviews were conducted face-to-face. Due to health security reasons, online interviews were also acceptable. The interviews were conducted in Ukrainian, Russian, or Polish. An interviewee could decide which language he/she preferred to speak. IDIs lasted between 21 and 72-min. Face-to-face interviews were audio-recorded. Online interviews were video-recorded. All respondents were assured of their anonymity and they were asked to consent to participate in the study and to the audio(video) recording. To analyse the research data, the IDIs were fully transcribed and translated into Polish and into English.

All qualitative data were analysed using a tool developed by the authors of the study. The tool enabled us to select and distinguish all types of capital used by interviewees in different periods of time (Appendix A).

\section{Results}

\subsection{Employment of Migrants from the Employers' Perspective}

Most respondents were representatives of small and medium-sized firms $(70.95 \%$ and $19.29 \%$, respectively). The percentage of workforce comprising migrants varied across industry sectors and firms. The average share of migrant workers was $17 \%$ and median was $10 \%$, while three-quarters of all surveyed firms employed between $10 \%$ and $25 \%$ of foreigners. The highest percentage of migrant workers was found in the smallest firms, where almost one-third of all employees were migrants, and in companies which operated in such sectors as transportation and storage, accommodation and food service activities, and other service activities. For these sectors, the average percentage of migrant workers was reported to be between 26 and $31 \%$.

Although there were reports on lower demand for labour and job losses resulting from the COVID-19 pandemic, especially during the first several months of the economic downturn [32,33], the majority of the surveyed firms (62.1\%) did not experience a negative impact of the pandemic on the employment of migrant workers. In the case of native workers, $67.9 \%$ of surveyed employers reported no impact. Overall, there was a very small difference in employers' perceptions on how the pandemic affected the number of employed migrants compared to natives (Figure 4). The decline in employment of migrant workers was observed more frequently $(30.5 \%)$ than that of native workers $(22.6 \%)$. Also, the percentage of companies which observed a rise in the employment of natives was slightly higher than those declaring an increase in the employment of foreigners $(8.1 \%$ and $3.3 \%$, respectively).

When assessing how the number of foreigners answering job offers changed as compared to the situation from before the COVID-19 outbreak, the majority of the surveyed employers $(47.9 \%)$ reported no impact. More than one-third (34.8\%) of respondents indicated a decrease in the number of non-native candidates, and only one in sixteen companies $(6.2 \%)$ reported an increase in the number of migrants applying for the jobs.

Despite the economic shock, most of the surveyed firms (41.4\%) expected the demand for foreign labour to remain the same over the next 12 months. Only $15.5 \%$ of employers stated that this demand will decrease, while according to $21.2 \%$ of the respondents it will increase. When it comes to a longer time perspective, employers seem to have a more optimistic view: $30.2 \%$ of respondents do not expect the demand for migrant workforce to change in a three-year period and the same percentage of respondents could not make a clear statement on this issue. In the remaining cases, employers are three times more 
likely to anticipate that the demand for migrant workers will increase $(30.5 \%)$ rather than decrease $(9.1 \%)$.

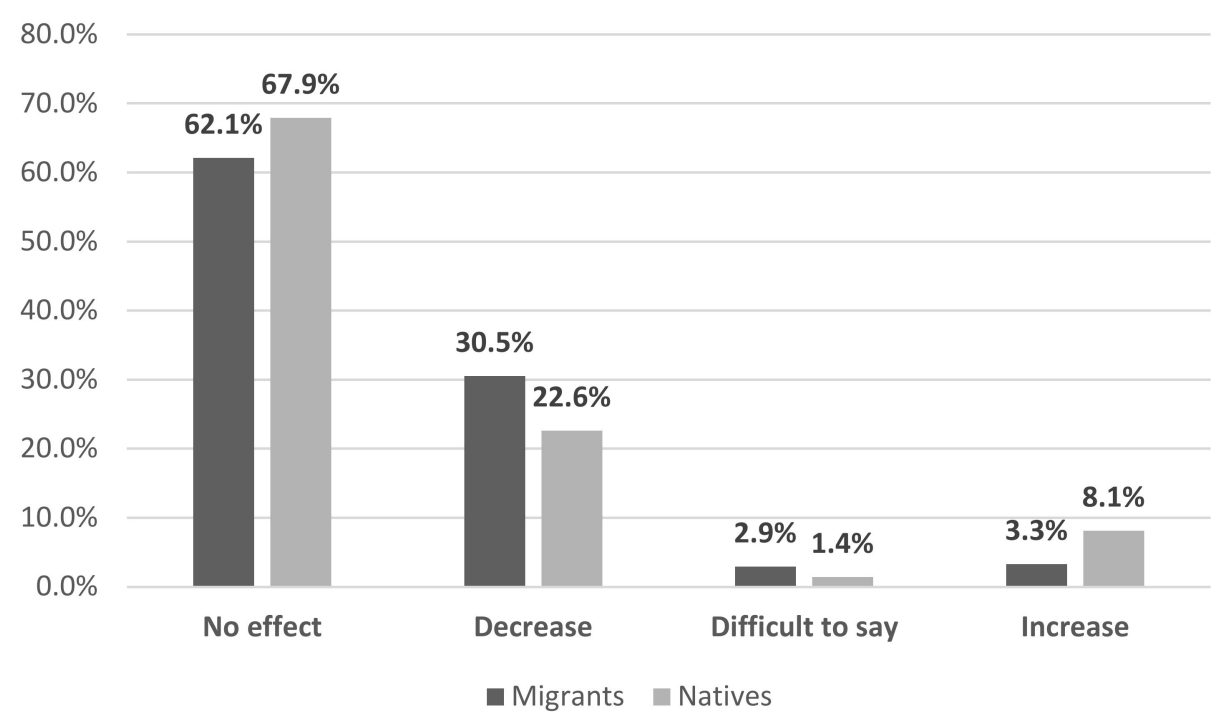

Figure 4. Employers' perceptions of the impact of the COVID-19 pandemic on the employment of migrant and native workers. Source: Own elaborations.

From the perspective of Bourdieu's theory of capitals, employers' support can have a direct impact on a migrant's capital availability. Almost $2 / 3$ of the surveyed firms from the Poznań agglomeration (64.1\%) declared being engaged in activities addressed to migrant workers. Two most frequently occurring forms of these activities include support in dealing with administrative matters (e.g., related to the legalisation of stay, $78.8 \%$ ) as well as support in dealing with residence issues (e.g., housing, finding a general practitioner, etc., $59.5 \%$ ). The most popular forms of employers' support can help to create and develop symbolic capital.

The next, in terms of frequency of indications reported and form of support, provided information on various aspects of life in Poland (33.5\%). This form seems to be the first that could actually improve the employees' functioning in the new environment without direct benefit for the employer. This kind of activity is useful in terms of developing cultural capital that can be converted in symbolic capital.

More than $1 / 5$ of the surveyed employers $(22.7 \%)$ reported providing additional financial support that goes beyond remuneration (e.g., subsidised accommodation, meals, etc.). This kind of activity results in developing economic capital. Social capital of employed migrants can be improved by actions facilitating integration of non-national employees, which was reported by only $9.3 \%$ of surveyed firms. A small percentage of employers reported financing language courses, either general language courses $(3.7 \%)$ or job-specific Polish courses $(3.0 \%)$, that can result in developing migrant workers' cultural capital.

\subsection{Migrants' Adaptation Strategies}

In this section we developed the typology of migrants' adaptation strategies to the labour market. We extracted the current and future goals of each migrant. On the basis of the key elements of these goals, we developed eight types of strategies (Table 2). Each strategy is briefly described in the table below with examples of quotations from the IDIs. 
Table 2. Typology of migrant's strategies of adaptation to the labour market.

\begin{tabular}{|c|c|}
\hline Strategy Name & Key Elements \\
\hline Persistent climbing & $\begin{array}{l}\text { Professional development, personal growth, general improvement of the situation, } \\
\text { consistency in achieving the goal, having a detailed plan of action, perseverance in pursuing } \\
\text { professional goals, professional competences, knowledge of Polish }\end{array}$ \\
\hline Gold rush & $\begin{array}{l}\text { Making money, capital accumulation, achieving higher quality of life, investing for profit, } \\
\text { financial transfers to Ukraine, increasing wages, realistic short- or medium-term } \\
\text { professional goals, social contacts mainly with Ukrainians }\end{array}$ \\
\hline Putting down the roots & $\begin{array}{l}\text { Life stability together with economic security, willingness to assimilate (e.g., learn Polish, } \\
\text { graduate) and develop professional skills in the host country, Poland perceived as a good } \\
\text { place to live, prospects for the family are important }\end{array}$ \\
\hline Insider-outsider/victim & $\begin{array}{l}\text { Fight (alone) for your right, belief in the worse situation of migrants in the labour market, } \\
\text { soft discrimination, no or marginal social contact with Poles }\end{array}$ \\
\hline Waiting for the sun or stagnation & $\begin{array}{l}\text { High level of dependence on external circumstances, 'nothing depends on me', taking what } \\
\text { fate brings, living in the present, no or little involvement in studying, fake stabilization }\end{array}$ \\
\hline Lost in the future & $\begin{array}{l}\text { No clear idea for the future professional development, unrealistic and/or volatile } \\
\text { goals/plans, choosing between failed alternatives, not considering consequences or } \\
\text { side-effects of present choices, qualifications, and skills inadequate for the (professional) } \\
\text { goals, highly uncertain economic situation }\end{array}$ \\
\hline Step back & $\begin{array}{l}\text { Conscious degradation of one's socio-professional position, job below one's qualification, no } \\
\text { professional development, going with the flow }\end{array}$ \\
\hline No surprises & $\begin{array}{l}\text { No particular expectations and aspirations, working in a position related to } \\
\text { education/experience, basic goals connected mainly with the economic security, closed in } \\
\text { one's own world }\end{array}$ \\
\hline
\end{tabular}

Source: Own elaborations.

\section{- Persistent climbing}

The respondent came to Poland 12 years ago for his master's studies. He also defended his Ph.D. and currently works at the university as a lecturer, as well as a specialist in the international affairs department. He is optimistic about his workplace, and spends a lot of time working and seeking to undertake various initiatives aimed at the development of the university as well as himself.

I gradually start to build a vision of the future, for example, to grow, to do something, for example, in two years or five years, to achieve a higher place in the hierarchy in my workplace.

The respondent identifies himself strongly with his workplace and strives to make the company's position as high as possible. He maintains that the outbreak of the pandemic has had a positive impact on both his ability to achieve professional goals and on the improvement of his economic conditions. During the pandemic, the respondent was able to focus on the development of projects and planning of his own professional development strategies.

Finish those projects that are already started, prove to everyone that there is a lot of potential. Try to develop the section I work in.

The most severe impact that the respondent experienced was the restriction on social contacts with colleagues and limited travel opportunities. According to the respondent, his most important qualities were discipline, creativity, and foreign language skills.

All fields of capital are well-developed in this case. The respondent has awareness of his strengths (symbolic capital), has strong language skills (cultural capital), recently improved his economic situation-bought a flat (economic capital) and has good relations with his co-workers (social capital). The pandemic situation is seen not as a threat, but as an opportunity to focus on his professional development. 


\section{- Gold rush}

The respondent came to Poland with her child 2.5 years ago to join her husband, who had been worked in Poland for a while. The respondent's goals are strictly defined, that is achieving a higher quality of life (mainly understood as the improvement of financial conditions).

I invested money in myself, I studied, wanted to earn more, move on. (...) you also have to invest in yourself, learn (... ). Every time you go to training, extra training, you increase the price of your services, you grow as a master.

The key element of the strategy is qualifications development in order to open one's own business. These are intermediate goals, which are to contribute to achieving the main goal. The realization of the intermediate goals requires financial resources (the invested money is to be returned with profit in the future).

First, finances. Savings, money will help to open a dealership and buy an apartment. A car will get me to school and on business.

Before the pandemic, the respondent's strategy was gradually implemented (participation in courses, higher earnings), but the plan was shaken by the effects of the COVID-19 pandemic (reduced number of clients, lower income). The implementation of further actions is postponed (the change of workplace, opening her own business). The respondent describes the chances of implementing the plan as " $50 / 50$ ".

In this case, economic capital comes to the fore. The activities of the respondent are subjected to her goals and connected with increasing her income. The other types of capitals are used to convert them to the economic capital (development of qualifications to earn more).

- Putting down the roots

The respondent came to Poland with her family five years ago to achieve specific goals (life stability with prospects for herself and her family) and plans, which were later elaborated in more details. A key element of the strategy is "rooting" in a large city. The respondent perceives Poznań as a good place to live, suitable for achieving life stability in various fields. Before the pandemic, the respondent achieved the main goal.

I was rooted. (...) It was a normal life. In my opinion, the way it was supposed to be.

However, this situation was shattered by the effects of the COVID-19 pandemic (reduced amount of work to be done, less income, blocked opportunities to pursue educational plans). The respondent shows determination to develop the capitals which she possesses and readiness to expand them, but the turning point-the outbreak of the pandemic -turned out to be a factor which significantly limited her possibilities.

As the epidemic started, from March onwards, a lot of companies closed down, there was less work, wages also decreased, there was a material deterioration in 2020.

The respondent relies mainly on the social capital "imported" from her home countrycontacts with family and friends from Ukraine. We do not know what the level of social capital built in the host country really is. The respondent claims that she still relies on "the same people" but, at the same time, she was successful in attracting clients for her cleaning services in Poland.

- Insider-outsider or victim

The respondent came to Poland to join her husband, who had been working in Poland for some time. Her goal is to provide a good education for her daughter. The respondent accepts jobs below her qualifications. Her professional aspirations are not high, and she does not speak Polish well, so her level of symbolic and cultural capital is low.

She experiences unequal treatment (lower salary of her husband, people "looking down" on her, rudeness, ignorance, distance in relationships with co-workers). The sense 
of discrimination was reinforced during the prolonged administrative proceedings related to the issue of her residence permit in Poland.

Even in conversation one feels that I am here and you are there. I am above and you are below. I am in my country, in my place, and you are a guest.

The situation is not "black and white". The respondent also stresses the support offered by her supervisor which, in fact, was significant (offering accommodation, help in finding an apartment, help in getting her daughter education admittance). The respondent's strategy for overcoming inequality and improving her situation is to prove that she is a valuable employee.

I would like to gain more respect to go further in my career. In the bakery, hard work is required and you have to show that you can work much better than others.

Communication in Polish is seen as helpful in relationships in the workplace. However, the pandemic caused significant uncertainty concerning employment in her case.

The strategy is based on a symbolic and cultural capital, but in a negative sense. The respondent perceives social differences between Poles and migrant population to be large. This results in the lowering of both social status, social trust, and safety.

- Waiting for the sun or stagnation

The respondent came to Poland to achieve his economic goals. He worked in various cities in Poland. When he finally managed to stand on his own feet and moved to Poznań, he invited his family to come to Poland. Currently, he is employed in a construction company, where his few friends from Ukraine also work. The respondent's main capital is the cultural capital-the experience he gained after coming to Poland, as well as the skills and knowledge he acquired in his current job (e.g., he learned how to operate a plastering machine). In addition, the respondent has learned the Polish language on his own. Thanks to his proficiency in Polish, he was quickly promoted in his first job. In the future, he plans to settle down in Poland permanently. His main goal is to grow professionally (he emphasises that he does not want to work as a physical worker for the rest of his life). He also thinks about starting his own business and inviting his Ukrainian friends to come to Poland.

For example, the guys from my technical school where I studied. When I served in the army, I also met a lot of good people. I would like to bring them over here with me, as well.

However, his goals regarding his professional development are not specified and he does not take any specific steps to achieve them. He recognizes the impact of the pandemic not only on the public institutions (e.g., long queues in offices), but also on the construction industry (e.g., delays in the supply of materials which cause downtime and elimination of bonuses for extra work). This situation makes him feel insecure.

I can describe it like this: something is constantly bothering me. Something like a sense of danger ... It's hard to face it on a daily basis.

The strategy relies on the cultural and social capitals which are converted into the economic capital. The basic capital is the social capital, which provides a relatively stable employment, and will be further developed by strengthening contacts with his friends from Ukraine. The sense of uncertainty associated with the COVID-19 pandemic does not translate into taking actions to overcome the difficulties, but rather contributes to the inertia in everyday life.

- Lost in the future

The respondent came to Poland to get higher education. The respondent attempted three times to study at the university, but each time she dropped out. Despite her young age, she tries to make the most proper decisions. However, her choices do not seem to be well-thought-through and are fraught with the risk of mistakes resulting from the lack of 
life experience, confusion, and acting like a "child in the fog". For example, the respondent, after returning back to work at the restaurant, decided to change her apartment for a more expensive one, not anticipating that the restaurant may close again.

(... ) in the summer, I moved to a new apartment, which is bigger and more expensive. It's in the center of Poznan and costs more, but we didn't expect the same situation as in March to happen again. Now it is hard for us to pay for it.

The closure of the restaurant mobilized the respondent to look for an alternative profession, namely providing manicure services. The new profession brings income (which proves the respondent's resourcefulness, ability to cope with the financial difficulties), but the choice of the industry raises doubts (the cosmetics industry, like the restaurant industry, is strongly affected by the pandemic and therefore the activity is conducted illegally. The respondent has no knowledge about taxes, the business is undertaken in violation of the sanitary restrictions, etc.). She ignores the potential consequences of her actions.

That is why I do it exclusively at home now. When you serve clients in your home, it always has to be clean, which means I have disinfectants, floor cleaners, dusters, etc.

Despite her reduced income, the respondent undertook paid studies (still in a field burdened with strong uncertainty about the future-tourism and recreation). In addition, during the interview, the respondent did not consider whether and how the food service industry would function after the pandemic.

The strategy bases mainly on a negative symbolic and cultural capital. The characteristic issue is misidentification of resources and opportunities. Actions taken are not matched with professional skills. As a consequence, the strategy is vulnerable to failure.

\section{- Step back}

The respondent knows his technical qualifications are worth more than his master's law degree. Even with a Polish university degree, he may have difficulties to "stand out" from the large group of Polish graduates without a job. Although the stagnation in the professional life of the respondent that has lasted for several years, he claims that he has never given up his ambition to develop professionally.

I always considered my current job as temporary. I wanted to get to the university, but it is not that easy. You must pay for living, cover other expenses, pay for the trips to Ukraine. So, the temporary job has become permanent.

It is interesting that the lack of possibility of realization of professional development plans (getting higher education in Poland, finding a well-paid job that matches his qualifications) concerns a person with such rich resources. He possesses all types of capitals: social (a large circle of supportive friends and family, numerous acquaintances with a fairly high social status, supportive co-workers), cultural (developed soft skills, law degree, technical professional qualifications), economic (relatively good earnings), and symbolic (good knowledge and confidence in the level of his skills).

The situations encountered at each stage of the respondent's history in Poland force him to choose some forms of capital over others. His narration is characterized by a bitter realism, the rationality of an educated and ambitious man, who must "grit his teeth" to ensure a decent survival for himself and his family, pushing his dreams of self-development into the background.

When living as a migrant worker in a foreign country and having children, it is not easy being jobless because you have to pay the bills.

As much as he is convinced that his qualifications will allow him to find a better employment, he has doubts regarding the possibility, but also the sense of applying for higher education.

The strategy relies on a negative symbolic capital. In this case it is visible as an erosion of the competences and working below one's skill level. Paradoxically, it is quite 
resistant to economic shock. Social capital is also widely used, however, not to pursue professional goals.

- No surprises

The respondent came to Poznan to find a job and to improve his family's financial situation. He has vocational education and is employed in an industry which matches his formal qualifications. However, he has no plans regarding his professional development.

We don't have the opportunity to move up the career ladder. You have to understand that Ukrainians will not go high. Production line operator-and there is no other career.

The respondent is satisfied with the current work and the salary. He had obtained some basic language skills before he started to work in Poland. He also believes that better language skills would help him to gain a higher job security:

I would like to have a better command of the Polish language. If you speak Polish well, you can find a better job. There are Polish language courses for foreigners in Poznan.

The respondent does not have high career expectations. He is satisfied with the social benefits provided by his employer (e.g., a Christmas bonus). Social security benefits are also important to him. He does not have high expectations for the future. His main goal is to buy an apartment, which he sees as an opportunity to improve his economic situation:

If Poles have their own apartment, it is better for them. They are also paid 500 zlotys [of child allowance] and save.

This strategy is based almost solely on the economic capital provided by the current employer and Polish social security system. The cultural capital is used and converted within a limited scope.

Finally, in Figure 5, we present the potential impact of the COVID-19 pandemic shock on each of the extracted strategies. The position of given strategy on the $X$ axis defines its sensitivity to pandemic (from very low to very high level). This impact is highly diversified. Our findings suggest that the most vulnerable strategy is 'persistent climbing' which is often connected with specific personal attributes as perseverance, persistence, consistency in achieving the goal, and professional ambitions. We conclude that this set of characteristics may be helpful in the case of adverse external circumstances. On the other side of the spectrum, one can notice the 'lost in the future' and 'waiting for the sun' strategies. These, in turn, can be connected with passivity, lack of planning and no entrepreneurial skills.

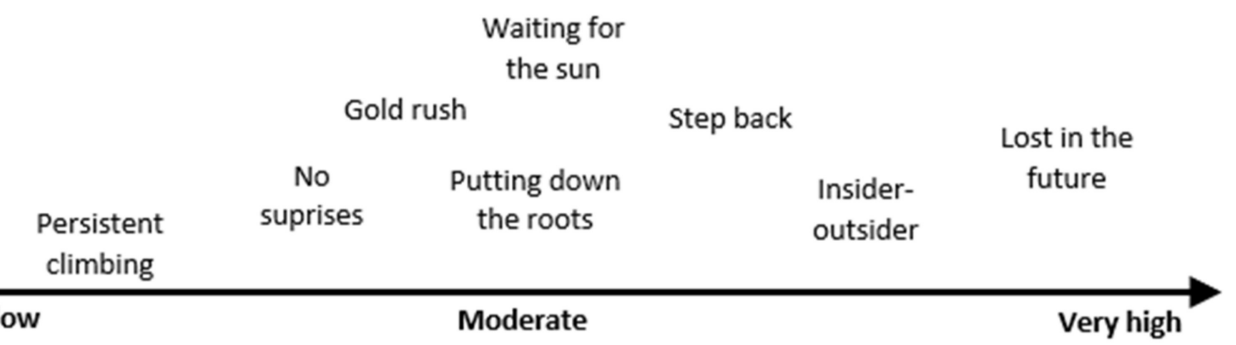

Figure 5. COVID-19 impact on extracted adaptation strategies. Source: Own elaborations.

\subsection{Capital Conversion}

The strategies of the interviewed immigrants, presented within the eight types above, are based on mutual conversion of Bourdieu's four basic types of capital. In the following section, firstly, we present the types and forms of capital which the Ukrainian migrant workers own or possess (Table 3). Secondly, we elaborate on how they produce, apply and mutually convert their assets in the process of implementation of their own strategies of adaptation to the labour market of the Poznan agglomeration under the conditions of the COVID-19 pandemic. 
Table 3. The identified forms of capital used by the migrant workers in their adaptation strategies.

\begin{tabular}{|c|c|c|c|}
\hline \multicolumn{4}{|l|}{ Bourdieu's Capitals } \\
\hline Symbolic & Economic & Cultural & Social \\
\hline $\begin{array}{l}\text { Legal Basis for Residence in } \\
\text { Poland: } \\
\text {-visa, residence card } \\
\text { (temporary or permanent), } \\
\text { Pole's Card-and privileges } \\
\text { associated with them } \\
\text { Place in a Formal Work } \\
\text { Hierarchy: } \\
\text {-form of employment: } \\
\text { employment contract, civil } \\
\text { contract, freelancing, } \\
\text { self-employment, } \\
\text {-full-time or part-time } \\
\text { contracts, } \\
\text {-job position and professional } \\
\text { advancement or degradation } \\
\text { Social Status: } \\
\text {-receiving own socio-economic } \\
\text { position in relation to: Polish } \\
\text { citizens, other Ukrainians } \\
\text { living in Poland or in Ukraine, } \\
\text { earlier position in Poland or in } \\
\text { Ukraine, } \\
\text {-general potential of an } \\
\text { individual, as seen by others } \\
\text { (employer's, co-worker's, } \\
\text { family's opinion) } \\
\text { Self-Esteem: } \\
\text {-assessment of one's own } \\
\text { value as an employee, own } \\
\text { capabilities, skills and } \\
\text { qualifications, } \\
\text {-sense of: independence, } \\
\text { comfort, stability, appropriate } \\
\text { behavior } \\
\text { Sense of Security: } \\
\text {-economic (guaranteeing } \\
\text { economic self-sufficiency for } \\
\text { oneself or for one's family, } \\
\text { maintaining a stable job), } \\
\text {-social (e.g., access to nursery } \\
\text { school), } \\
\text { thealth (access to health care, } \\
\text { threat of COVID-19) }\end{array}$ & $\begin{array}{l}\text { Employment: } \\
\text {-employment levels, } \\
\text { dependent on satisfaction } \\
\text { from earnings (e.g., well- or } \\
\text { badly-paid job, limitation of } \\
\text { working hours due to the } \\
\text { effects of the pandemic on the } \\
\text { labour market, getting an } \\
\text { extra job) } \\
\text { Finance: } \\
\text {-earnings-income from work, } \\
\text {-other money: bank credit, } \\
\text { savings, gifts, social benefits } \\
\text { (e.g., child allowance) } \\
\text { Other Tangible Goods: } \\
\text {-house leased by the employer, } \\
\text {-rented apartment, } \\
\text {-own apartment, } \\
\text {-house equipment, } \\
\text {-company car for the use of } \\
\text { the employee, } \\
\text {-own car, } \\
\text {-work equipment: computer, } \\
\text { access to the Internet, } \\
\text { materials and tools } \\
\text { Time: } \\
\text {-time spent on work, } \\
\text {-free time and forms of } \\
\text { spending it, } \\
\text {-time spent on producing one } \\
\text { type of capital at the expense } \\
\text { of another assets }\end{array}$ & $\begin{array}{l}\text { Knowledge of Language and } \\
\text { Culture: } \\
\text {-Polish (adjustment to values, } \\
\text { norms, behaviour patterns at } \\
\text { workplace or in a wider social } \\
\text { space, knowledge of cities, } \\
\text { social and cultural } \\
\text { infrastructure, } \\
\text {-Ukrainian and Russian (in a } \\
\text { specific job context, e.g., } \\
\text { companies employing many } \\
\text { Ukrainians or cooperating } \\
\text { with Eastern European } \\
\text { partners), } \\
\text {-other foreign languages } \\
\text { Professional Qualifications: } \\
\text {-university degrees, } \\
\text {-professional courses, } \\
\text {-other diplomas and } \\
\text { certificates, } \\
\text {-job-specific skills, } \\
\text {-working experience, } \\
\text {-industry and } \\
\text { occupation-specific } \\
\text { knowledge } \\
\text { Soft Skills: } \\
\text {-motivation, } \\
\text {-determination, } \\
\text {-self-organization, } \\
\text {-composure, } \\
\text {-resistance to stress, } \\
\text {-resourcefulness, } \\
\text {-communication skills, } \\
\text {-courage, } \\
\text {-etc. }\end{array}$ & $\begin{array}{l}\text { Family: } \\
\text {-close relatives (spouse, } \\
\text { partner, parents, siblings), } \\
\text {-Polish relatives } \\
\text { Friendships: } \\
\text {-close Ukrainian friends in } \\
\text { Ukraine, Poland and other } \\
\text { countries, } \\
\text {-close Polish friends, } \\
\text {-foreign friends } \\
\text { Acquaintances: } \\
\text {-Polish colleagues, } \\
\text {-Ukrainian colleagues or } \\
\text { Ukrainian classmates from } \\
\text { Polish language courses, } \\
\text {-international colleagues, } \\
\text {-people met occasionally, e.g., } \\
\text { clients, landlords, flatmates } \\
\text { Professional Relations: } \\
\text {-employers, } \\
\text {-co-workers from various } \\
\text { levels of professional } \\
\text { hierarchy } \\
\text { Professional Support: } \\
\text {-Polish teachers, psychologists, } \\
\text { mentoring professionals } \\
\text { from work }\end{array}$ \\
\hline
\end{tabular}

Source: Own elaborations.

Our main conclusion drawn from the investigation of the capital conversion is that all types of capitals (symbolic, economic, cultural, and social) can be transformed into one another. The basic process of capital conversion is a direct transformation of one type of capital into another, where the immigrant possesses a given asset which then gets activated and eventually 'invested' into action (aiming to produce a transformed asset) and is important for the immigrant's current interests and priorities.

However, we identified some regularities and patterns specific for the analysed conversions, as there seems to be a big set of forms (real-life examples) of the capital used by the interviewed Ukrainian immigrants which can be transformed in many different 
configurations. Simple transformations of one form of capital into another is a part of more complex processes. Thus, conversion in various cycles is possible.

As the analysis of empirical data revealed, specific assets are transformed into some forms of capital more often than into others. Moreover, some of them seem to be important for our respondents' professional development as 'means of production', while others are more important as 'goals' in a conversion process. Another important factor to consider is that, in many cases, such conversions of capital forms might go not only unidirectional, but are in essence bidirectional and therefore intertwined (e.g., economic capital $\leftrightarrow$ cultural capital). Furthermore, we present the types of capital conversion which are the most characteristic for the group of migrant workers that took part in our research.

The important type of the 'start-up capital' (the asset used at the beginning of the individual strategy implementation) was the social capital for a significant part of our interviewees (Figure 6). It seems to be common among Ukrainian immigrants to use their contacts in a professional context (e.g., good relationships with compatriots who worked in Poland before or Poles who help to find employment, or employers offering a house to rent). Also, family or friends' support in taking care of children helps some interviewees to get a job and achieve a work-life balance. Otherwise, some interviewees had plans to use their present contacts with clients of the company they worked for to build a network of customers for their own businesses. It is worth noting that none of the respondents have perceived institutional contact network (e.g., with the immigration office, NGOs) as a crucial factor in achieving their goals.

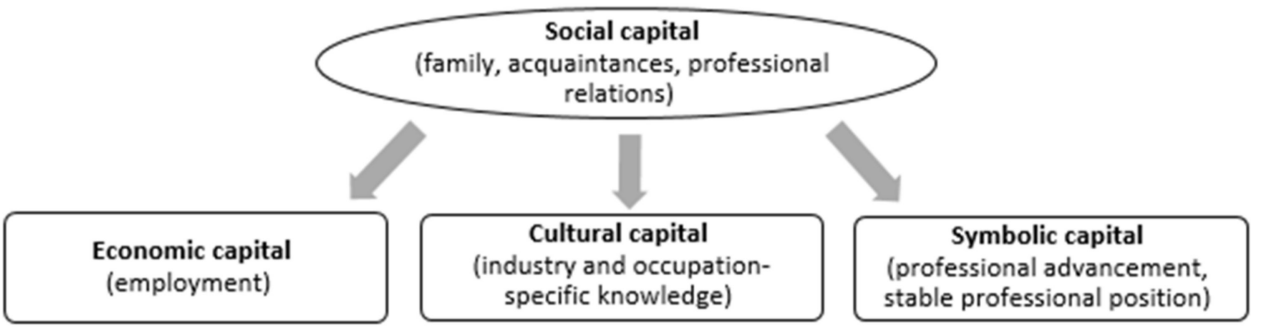

Figure 6. Social capital conversions. Source: Own elaborations.

Various types of contacts (with family, acquaintances in Ukraine and Poland, clients, co-workers, employer) are also an excellent opportunity for immigrants to learn industry and occupation-specific knowledge and skills, and thus it helps them to improve their professional skills. White-collar relationships help especially in gaining educational and career opportunities for whole migrant families (e.g., finding a good school for children, or gaining knowledge about how to start and run their own businesses).

Reflection in the eye of the beholder, especially related to professional relationships (employer, co-workers, clients), is one of the most important assets which helps the interviewed immigrants strengthen their self-esteem and their status as employees and citizens of the Poznań agglomeration. Mutual appreciation, trust and motivating one another builds a coherent group of co-workers from various countries and levels of professional hierarchy, offers wider possibilities of providing professional advancement, work organisation and security of residence (residence card, Pole's Card), and helps immigrants to build a sense of security and being a valued member of the Polish society.

Our respondents commonly convert their finance (from any sources), private or company car, work tools and materials into a form of improvement of their professional qualifications such as higher education, specialist courses taken for specific professions, or self-education (Figure 7). 


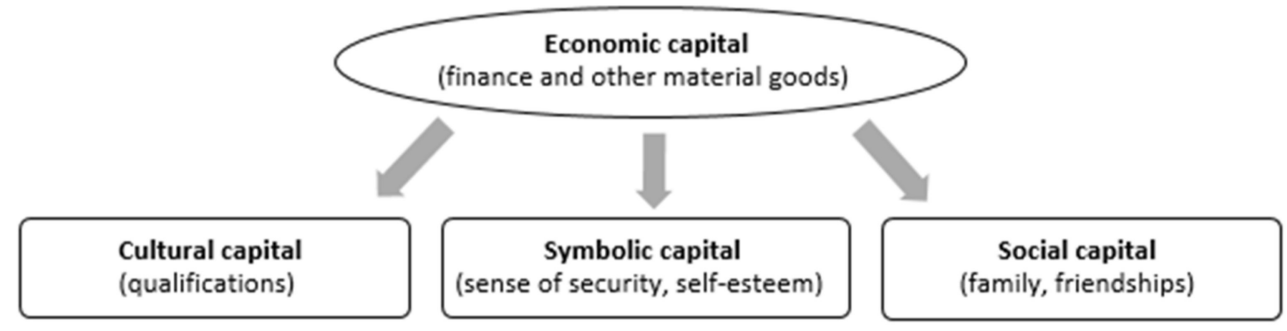

Figure 7. Economic capital conversions. Source: Own elaborations.

Economic capital, like satisfactory earnings or having a flat, also allows our interviewees to achieve a higher self-esteem and self-confidence, strengthens the sense of comfort and independence from the employer or family members.

On the other hand, access to the internet and a personal computer or a laptop helps immigrant workers to maintain relationships with their loved ones living abroad such as close relatives, a girlfriend/a boyfriend, or friends.

In our interviewees' individual strategies, their cultural capital, such as their ability to speak and easily understand Polish and/or any other foreign language, soft skills, and professional qualifications, is not only converted into the current employment, but is also taken as a future asset to 'invest' into their own business (Figure 8). Being put in a situation of labour uncertainty related to problems with the legality of residence, determination and self-motivation are the real values helping immigrants to sustain their employment status. In some cases of migrant workers, the higher the education level they achieve, the higher salary they are able to receive (which might depend on the current condition of the labour market and situational circumstances, e.g., the effects of the COVID-19 pandemic).

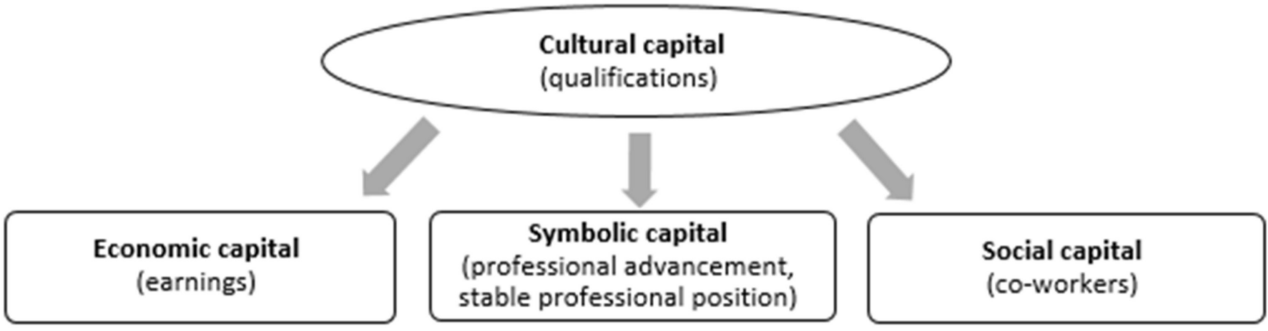

Figure 8. Cultural capital conversions. Source: Own elaborations.

In general, an aggregated cultural capital helps migrant workers in gaining appreciation and advancement in their professional environment. The specific case of conversion of the cultural capital into the symbolic capital of migrant workers in Poland is graduation from post-secondary school as a way of achieving the security of residence. For example, this allows foreigners to get a residence card and start their own businesses.

The combination of understanding and using the Polish language fluently, alongside with other soft skills (both non-verbal and verbal communication skills) can be a valuable asset of the cultural capital in the context of strengthening relationships with compatriots (helping those who do not know Polish very well) and building a network of contacts useful in a professional environment. Soft skills related to teamwork (diligence, motivation to work and being committed, ability to work fast and under pressure but being precise and committed at the same time) may help immigrants improve their relations with fellow co-workers.

A form of a symbolic capital asset (Figure 9), which is particularly valuable and important for the interviewed migrant workers, is a document confirming the legality of their residence. A residence card or a Pole's Card gives an immigrant a number of privileges (e.g., a child allowance). Other forms of the symbolic capital related to one's self-esteem and a sense of security help immigrants to earn equal and fair wages (compared to Poles or other legal residents) or to find a job under any circumstances. 


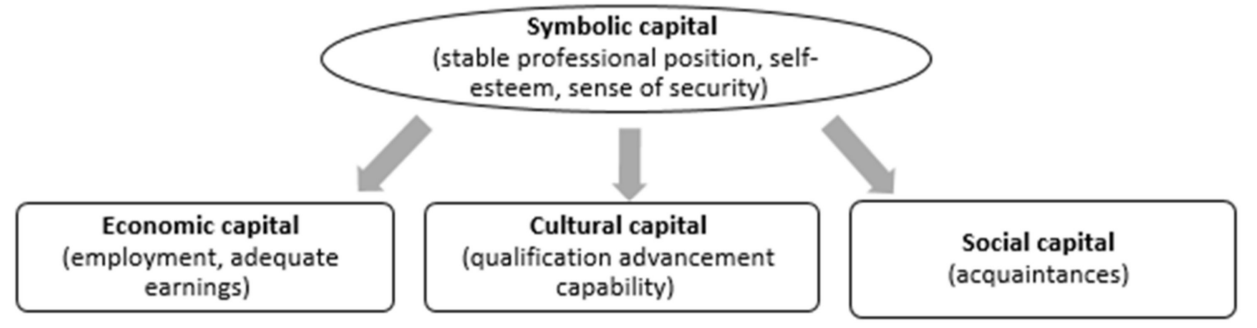

Figure 9. Symbolic capital conversions. Source: Own elaborations.

Support from the co-workers and management, as well as appreciation in the professional environment play a significant role in building higher motivation to self-educate, improve professional qualifications and, what is especially important, give access to professional courses and training.

The specific case of migrants' symbolic capital conversion is when they choose higher wages at the expense of the professional prestige (e.g., a highly educated man working as a truck driver). However, another form of this asset (his/her knowledge and competence) are still high enough to make a close relationship with the people who are highly-ranked in the professional hierarchy.

\subsubsection{Capital Conversion within the Same Type}

Immigrants convert not only one type of capital into another. They also transform capitals within the same type. For example, cultural capital (like self-motivation) is converted into another form of the same capital, for example attending courses or self-study for the improvement of working skills. In the case of economic capital, immigrants usually convert earnings into their own flat, working tools or savings which they would like to invest into their own businesses. The decrease in earnings caused by the COVID-19 pandemic is making this conversion impossible at times. Therefore, their plans of running their own business or purchasing an apartment in Poland must be postponed for later.

While analysing the conversion within symbolic capital, we noticed that immigrants who are focused on opinions or emotional support of other people (e.g., friends, colleagues, head of the company) can enhance their self-esteem or sense of security in the host community in this way.

The specific process in the COVID-19 pandemic is transformation within symbolic capital, which is directly connected with a lack of job security. Immigrants are concerned about the stability of their employment and worry that they might become redundant. They heavily rely on opinions of other people in maintaining the high levels of their working skills and a stable self-esteem. They also notice the equal status with their Polish colleagues (Polish employees also experience the lack of job security).

I can see how this pandemic has influenced the labour market, that Poles are very worried about being unemployed. The bakery [where I work] also hires Poles. ( . . ) the head of the hall-bakers who have been doing this work for 20 years, even agree to transport goods, clean, wash with me. Just so they have a job, so that they are not fired. ( . . . ) Everyone stays where they can, everyone tries to make a living.

We were also able to observe an interesting transformation process that concerns the social capital: the decrease of one form of the social capital (e.g., relationship with relatives who stay in Ukraine) is replaced with another form of the same type of capital (e.g., friends or colleagues in Poland). For example, parents of one of the respondent are not able to support her in childcare, so she asks for help her Ukrainian friends who live in Poland. The other respondent misses her parents and grandmothers a lot, so she builds strong ties with her colleagues, now treating her team as a 'family'.

We managed to observe the similar process regarding economic capital. The decrease in earnings is compensated by social benefits offered by the government to entrepreneurs 
affected by the COVID-19 pandemic. Immigrants also take up extra jobs or work on the informal labour market aiming to compensate the decrease in their income.

\subsubsection{Deficit Capital Conversions}

Immigrants also convert capitals which they do not possess. We identify two processes: the shortage of one capital can produce the deficit of another type of capital, or capital shortage can trigger the increase of another type of capital. Both processes can be explained by the COVID-19 pandemic effect.

The decrease of earnings in the COVID-19 pandemic (the deficit of the economic capital) causes a "state of limbo", a sense of insecurity, the lack of job security (the deficit of the symbolic capital). Immigrants, whose income have decreased or become uncertain, have been forced to spend money in a more economical way and to be resourceful (increase of the cultural capital). They stopped visiting their home country because of excessive costs of COVID-19 tests. As a consequence, their social capital (relationship with relatives and friends in Ukraine) has been decreased.

The COVID-19 pandemic has caused negative economic consequences which have resulted in limited contacts with clients or a complete lack of them (e.g., restaurants, beauty salons). The decrease in the social capital is converted not only into a deficit in economic capital (lower incomes), but also into a deficit in symbolic capital. For example, the respondent, a petrol station worker, suffers from the lack of purpose, as his job is aimed to help and serve people.

The deficit in symbolic capital (e.g., the lack of job security, loss of professional position and social status, etc.) relates to the increase in the cultural capital. Immigrants who are at risk of redundancy are motivated to improve their working skills and to attend courses. A deficit in symbolic capital involving the lack of health security causes a deficit in social capital (immigrants are afraid of visiting their relatives in Ukraine). Moreover, the deficit in the symbolic capital (the lack of health security) is converted into the deficit in another type of the symbolic capital, namely a sense of lack of freedom (going out with friends or visiting relatives is not possible).

We also managed to identify two interesting processes which are not directly related to the COVID-19 pandemic. The low professional position (deficit in symbolic capital) can be compensated by a higher income (increase in economic capital). For example, one of the respondent decided to work as a driver, despite having a higher education, just to be able to make more money. On the other hand, an increase in symbolic and cultural capitals is converted into a deficit in social capital. The remarkable case of the other respondent shows how stronger self-esteem and higher qualifications are converted into keeping safe distance from Polish boss and colleagues.

I think she [my boss] appreciates me. ( . . ) I think she would lose a lot if I left. I think she is afraid of that. Maybe that's why she treats me well. (...) Polish colleagues are lazy. Not many of them are ready to invest in themselves without receiving anything in return in the first year. (... ) Polish colleagues say to me: "Are you crazy to invest so much money in yourself? What if you don't pay them back?" Do you understand? I don't know what to call it.

\section{Conclusions}

In this paper, we presented strategies of adaptation of Ukrainian migrant workers to the local labour market of the Poznań agglomeration. We conducted our research during the COVID-19 pandemic and, therefore, we focused on an impact of the economic shock on migrant workers. This perspective was analysed from three main points of view. Firstly, we presented some socio-economic background for the Poznan agglomeration. Secondly, we showed the results of the quantitative survey of employers and presented their opinions about the impact of COVID-19 on migrant workers employment. Thirdly, we developed the typology of migrants' strategies of adaptation to the labour market. The typology was developed on the basis of 30 in-depth interviews with migrant workers from 
Ukraine. We used the Bourdieu capitals theory to identify the individual resources that migrants accumulate and convert to achieve their professional goals. The study confirms that Bourdieu's theory is also a useful tool in migration research and that it may be applied to distinguish and investigate the individual assets used in the adaptation to the labour market. We also assessed the impact of COVID-19 on the extracted strategies, which proved to be highly diversified.

The majority of employers claim that the pandemic did not affect migrant workers in a particular way. This is an important observation considering the findings from the qualitative research, where we found that the majority of extracted strategies suffer from the pandemic shock from a moderate to a high degree. Therefore, this is a clear inconsistency in the opinions of these two groups. The employers underestimate the impact of the pandemic on the situation of migrant workers.

The results of the study confirm that one's social network is important in the job searching process. The interviewees, similarly to other research studies, stressed the importance of individual contacts in getting information about jobs and navigation on the local labour market [41]. In our study, interviewees emphasized a need of having a native social network. Contacts with the host community were crucial for self-employed migrants.

The adaptation strategies refer to the research by [42]. The common problems of migrant workers were separation from the host-country labour market, working below one's skill level, promotion which is impossible or difficult in one's home country. We identified that the interviewees were usually ambitious and determined people, so we did not notice any case of long-term unemployment and reliance on social benefits. The respondents did not look for a job in Ukrainian companies and they were not separated from the Polish labour market. Even if they were self-employed, the host country social network was crucial for them. The respondents were conscious that the Polish language is important for getting both a well-paid job and a higher position, so they were motivated to learn it. It seems that the strong cultural capital of Ukrainian migrant workers, and the fact that Poland and Ukraine are neighbouring countries with strong ties, make integration into the labour market easier. When it comes to achieving their professional goal, many respondents rely primarily on themselves and their closest family members.

The characterized processes of capital conversion assume various schemes. Transformations from one capital to another or modifications within the same type of capital are possible. They can have a chain character (e.g., a job-seeking immigrant is supported by social network, and then his work provides him with a salary; the purchase of a flat is funded by his/her own savings) or of a circular character (e.g., higher qualifications let an immigrant earn more money, and then he invests his/her salary in another training aiming to gain a better-paid job position; strong self-esteem helps in gaining promotion at work, and then a higher job position enhances self-esteem). Deficit capital conversions are transformed in similar ways.

Advanced capital conversion processes involve transformation of different types of capital and various assets within the same capital. For example, one of the respondent found a job thanks to his sister-in-law. While working for the company, he has an opportunity to develop his social network. Relationships with other people will help him to set up his own business in the future.

The impact of the COVID-19 pandemic on the labour market and the requirement of new skills are stressed in research and media all over the world [32,38,43,44]. Migrant workers are ready for changes and motivated to match their skills to the demand in the hostcountry labour market regardless of the COVID-19 pandemic. Effective communication skills are as significant as before the COVID-19 outbreak. The interviewees stressed that those who speak other languages fluently have a better chance of getting well-paid jobs or being rehired.

Our study revealed that the activities undertaken by employers from the Poznan agglomeration contribute in a small way to the development of the economic, social, and cultural capitals of migrant workers. A majority of surveyed firms reported providing 
initial support that improved migrants' symbolic capital. This suggests that firms attract foreign labour according to their immediate needs, while not recognizing migrants' role in meeting long-term labour demand. Our findings highlight the marginal role played by employers in providing support that can help migrant workers in implementing effective strategies of adaptation to the labour markets by using and converting different forms of capital in the COVID-19 uncertain conditions.

Author Contributions: Conceptualization, P.C., O.S.-S., H.K., M.Ł., and M.W.; methodology, H.K., M.Ł.; investigation, P.C., O.S.-S., H.K., M.Ł., and M.W.; writing-original draft preparation, P.C., O.S.-S., H.K., M.Ł., and M.W.; writing-review and editing, P.C., O.S.-S., H.K., M.Ł., and M.W.; supervision, P.C.; project administration, M.W. All authors have read and agreed to the published version of the manuscript.

Funding: This research was funded by Adam Mickiewicz University in Poznan, Poland, grant number COV 14/2020.

Institutional Review Board Statement: Not applicable.

Informed Consent Statement: Not applicable.

Data Availability Statement: The data are available upon request from the corresponding author.

Conflicts of Interest: The authors declare no conflict of interest. The funders had no role in the design of the study; in the collection, analyses, or interpretation of data; in the writing of the manuscript; or in the decision to publish the results.

\section{Appendix A. The Analytical Tool Developed by the Authors of the Study}

Table A1. Part I. Demographics.

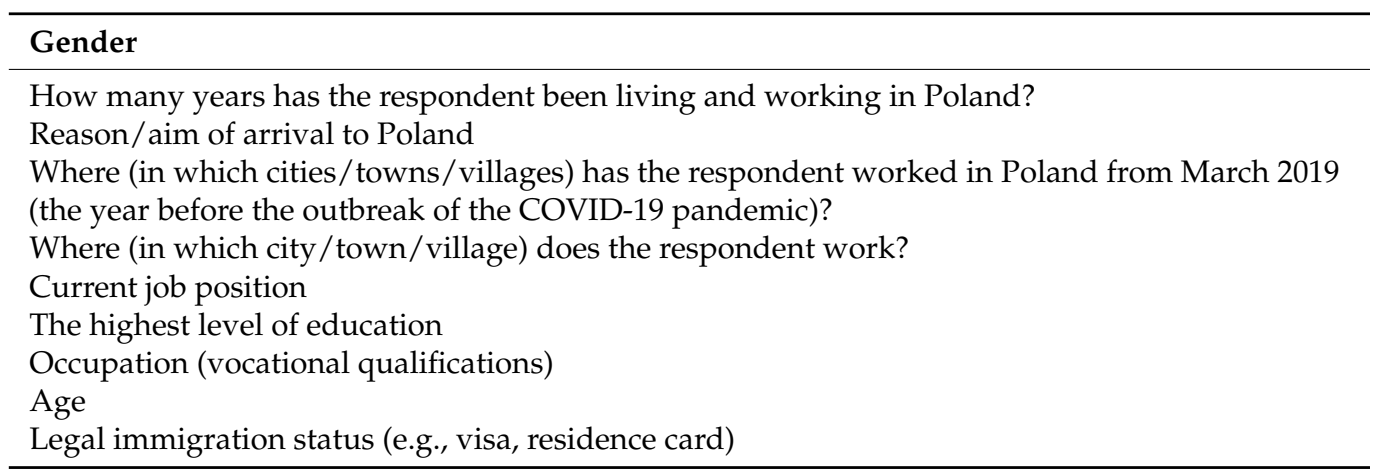

Table A2. Part II. Adaptation Strategy of the Respondent on the Labour Market-the Action Plan.

\begin{tabular}{|c|c|c|c|}
\hline \multicolumn{3}{|c|}{ Part II. Adaptation Strategy of the Respondent on the Labour Market-the Action Plan } & Comments \\
\hline \multicolumn{4}{|c|}{ 1. Goals-What Does the Respondent Want to Achieve? } \\
\hline Before the Pandemic & During the Pandemic & In the Future & \\
\hline \multicolumn{3}{|c|}{ 2. Capital(S)-What types of capital does the respondent use? How? } & Capital conversion! * \\
\hline \multicolumn{4}{|c|}{ Symbolic Capital } \\
\hline \multirow[t]{2}{*}{ Before the Pandemic } & During the Pandemic & In the Future & \\
\hline & Economic Capital & & \\
\hline \multirow[t]{2}{*}{ Before the Pandemic } & During the Pandemic & In the Future & \\
\hline & Cultural Capital & & \\
\hline Before the Pandemic & During the Pandemic & In the Future & \\
\hline
\end{tabular}


Table A2. Cont.

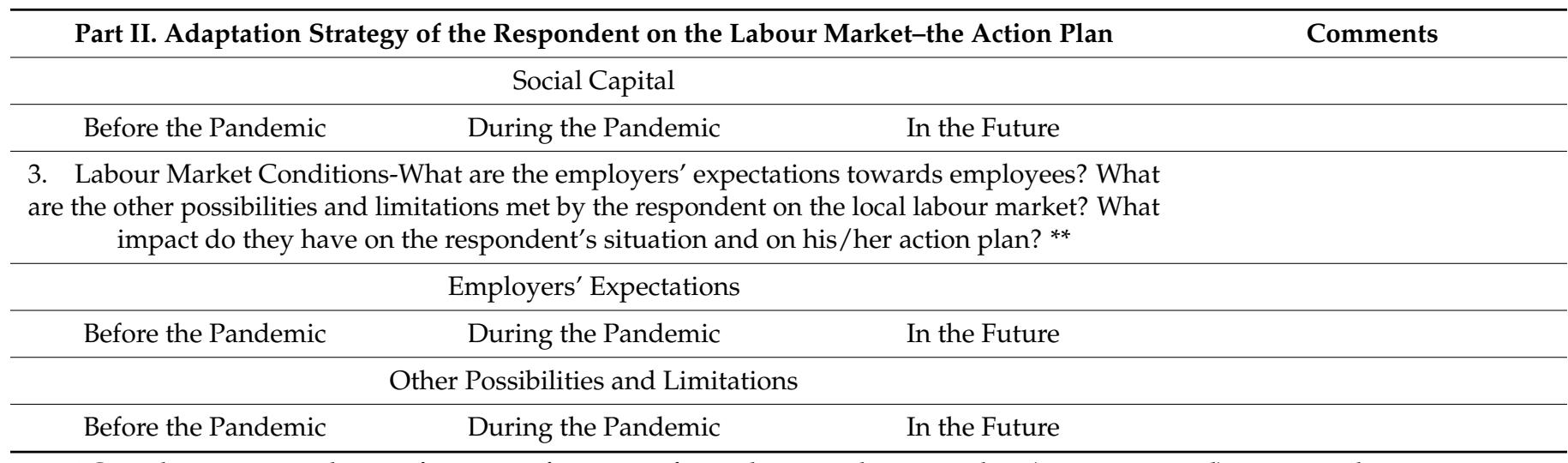

* Capital conversion is the transformation of one type of capital into another; e.g., salary (economic capital) is converted into training course and professional qualifications (cultural capital). The researcher can observe the capital conversion process during direct analysis of the respondent's statements. Here, in the table, we only record individual types of capital that played a significant role in the strategy of the respondent (the capital conversion process will be described in the Part III). ${ }^{* *}$ It is worth making notes on ideas for coping with the situation on the labour market.

\section{Part III. From Analytics' Point of View-Actual Qualitative Analysis}

1. After reading the transcript of the interview, describe in your own words the identified adaptation strategy of the respondent. Look at his/her situation from the perspective of an external observer, as a process taking place in the dynamic time perspective. Identify the most important elements, stages, turning points. Try to name the strategy.

2. Describe the capital conversion processes that were identified-how the respondent produced, used and converted particular types of capital [clarification: type of capital means economic, social, cultural, symbolic capital; forms of capital mean specific examples within particular types].

\section{References}

1. OECD. OECD Employment Outlook 2020: Worker Security and the COVID-19 Crisis; OECD Publishing: Paris, France, 2021; Available online: https:/ / www.oecd-ilibrary.org/sites/1686c758en/index.html?itemId=/content/publication/1686c758-en (accessed on 5 April 2021).

2. Bamieh, O.; Ziegler, L. How Does the COVID-19 Crisis Affect Labor Demand? An Analysis Using Job Board Data from Austria; Discussion Paper Series No. 13801; IZA Institue of Labor Economics: Bonn, Germany, 2020.

3. Lee, S.; Schmidt-Klau, D.; Verick, S. The Labour Market Impacts of the COVID-19: A Global Perspective. Indian J. Labour Econ. 2020, 63 (Suppl. 1), S11-S15. [CrossRef] [PubMed]

4. Dolado, J.J.; Felgueroso, F.; Jimeno, J.F. The Spanish Labour Market at the Crossroads: COVID-19 Meets the Megatrends; Discussion Paper Series No. 13869; IZA Institue of Labor Economics: Bonn, Germany, 2020.

5. Kaplan, G.; Moll, B.; Violante, G.L. The Great Lockdown and the Big Stimulus: Tracing the Pandemic Possibility Frontier for the U.S.; NBER Working Paper No. 27794; National Bureau of Economic Research: Cambridge, MA, USA, 2020.

6. National Academy of Sciences of Ukraine. Ukrainian Society: The Migration Dimension (УкраїнськеСуспільство: МіграційнийВимір); National Academy of Sciences of Ukraine: Kiev, Ukraine, 2018. Available online: https://www.idss.org.ua/arhiv/Ukraine_ migration.pdf (accessed on 5 March 2021).

7. Adams-Prassl, A.; Boneva, T.; Golin, M.; Rauh, C. Inequality in the impact of the coronavirus shock: Evidence from real time surveys. J. Public Econ. 2020, 189, 104245. [CrossRef]

8. Dang, H.-A.H.; Nguyen, C.V. Gender Inequality during the COVID-19 Pandemic: Income, Expenditure, Savings, and Job Loss. World Dev. 2021, 140, 105296. [CrossRef]

9. Meekes, J.; Hassink, W.H.J.; Klab, G. Essential Work and Emergency Childcare: Identifying Gender Differences in COVID-19 Effects on Labour Demand and Supply; Discussion Paper Series No. 13843; IZA Institue of Labor Economics: Bonn, Germany, 2020.

10. ETUC Report. Overlooked: Migrant Workers in the COVID-19 Crisis. 2020. Available online: https://www.etuc.org/en/ document/overlooked-migrant-workers-covid-19-crisis (accessed on 16 April 2021).

11. Edo, A. The impact of immigration on the labour market. J. Econ. Surv. 2019, 33, 922-948. [CrossRef]

12. Foucault, M.; Galasso, V. Working after Covid-19: Cross Country Evidence from Real-Time Survey Data: Science Po CEVIPOF Research Note \#9, May 2020. Available online: https:/ / spire.sciencespo.fr/hdl:/2441/5cmk499mce8lvosvi0jdis0dla/resources/ note9-foucault-galasso-.pdf (accessed on 16 April 2021). 
13. Duszczyk, M.; Matuszczyk, K. The employment of foreigners in Poland and the labour market situation. Cent. East. Eur. Migr. Rev. 2018, 7, 53-68.

14. Trzpiot, G.; Orwat-Acedańska, A.; Majewska, J. Analiza Regionalna Udziału Cudzoziemców na Polskim Rynku Pracy (Regional Analysis of the Share of Foreigners in the Polish Labor Market); Prace Naukowe Uniwersytetu Ekonomicznego w Katowicach: Katowice, Poland, 2020; pp. 90-109.

15. OTTO WorkForce. Opinie Pracowników Tymczasowych z Ukrainy na Temat Zadowolenia z Pracy w Polsce w 2020 Roku, Raport z Badania 2020 (Opinions of Temporary Workers from Ukraine on Job Satisfaction in Poland in 2020, Research Report 2020), Wrocław. Available online: https://cloud.ottoworkforce.pl/index.php/s/4GBMK5RpzKPHNz4\#pdfviewer (accessed on 18 February 2021).

16. Sterud, T.; Tynes, T.; Mehlum, I.S.; Veiersted, K.B.; Bergbom, B.; Airila, A.; Johansson, B.; Brendler-Lindqvist, M.; Hviid, K.; Flyvholm, M.A. A systematic review of working conditions and occupational health among immigrants in Europe and Canada. BMC Public Health 2018, 18. [CrossRef] [PubMed]

17. Dingel, J.I.; Neiman, B. How many jobs can be done at home? J. Public Econ. 2020, 189, 104235. [CrossRef] [PubMed]

18. Tacke, T.; Lund, S.; Manyika, J.; Thiel, L. The Future of Work in Europe: Automation, Workforce Transitions, and the Shifting Geography of Employment; McKinsey Global Institute: New York, NY, USA, 2020; Available online: https: / /www.mckinsey.com/featuredinsights / future-of-work / the-future-of-work-in-europe (accessed on 24 June 2021).

19. Clibborn, S.; Wright, C.F. COVID-19 and the Policy-Induced Vulnerabilities of Temporary Migrant Workers in Australia. J. Aust. Polit. Econ. 2020, 85, 62-70.

20. Odynets, S. Not really at home: Adaptation strategies of Asian migrants in Ukraine. Asian Pac. Migr. J. 2020, $29,422-443$. [CrossRef]

21. Churski, P. Rynek Pracy i Mobilność Sity Roboczej w Aglomeracji Poznańskiej (The Labor Market and Labor Mobility in the Poznań Agglomeration); Biblioteka Aglomeracji Poznańskiej nr 5, Bogucki Wydawnictwo Naukowe: Poznań, Poland, 2010.

22. Strzelecki, P.; Growiec, J.; Wyszyński, R. The Contribution of Immigration from Ukraine to Economic Growth in Poland: NBP Working Paper No. 322, 2020. 2020. Available online: https://www.nbp.pl/publikacje/materialy_i_studia/322_en.pdf (accessed on 5 March 2021).

23. Wadsworth, J. Labour Markets in the Time of Coronavirus: Measuring Excess; Discussion Paper Series No. 13529; IZA Institute of Labor Economics: Bonn, Germany, 2020.

24. Kubiciel-Lodzińska, S.; Maj, J. High-Skilled vs. Low-Skilled Migrant Women: The Use of Competencies and KnowledgeTheoretical and Political Implications: An Example of the Elderly Care Sector in Poland. J. Int. Migr. Integr. 2021. [CrossRef]

25. Orczyk, J.; Wozniak, M. The ins and outs of the Polish labour market. In Three Decades of Polish Socio-Economic TransfomationsGeographical Perspective; Churski, P., Kaczmarek, T., Eds.; Springer: Berlin/Heidelberg, Germany, 2021; In Press.

26. Jarecki, W. Imigracja z Ukrainy Jako Źródło Podaży Pracy w Polsce (Immigration from Ukraine as a Source of Labor Supply in Poland); Zeszyty Naukowe Wyższej Szkoły Bankowej w Poznaniu: Poznań, Poland, 2017; Volume 74, pp. 21-36. Available online: https://papers.wsb.poznan.pl/sites/papers.wsb.poznan.pl/files/ZN_WSB_P_ART/ZNPoz74_W_Jarecki.pdf (accessed on 11 March 2021).

27. Levytska, O.; Mulska, O.; Ivaniuk, U.; Kunytska-Iliash, M.; Vasyltsiv, T.; Lupak, R. Modelling the Conditions Affecting Population Migration Activity in the Eastern European Region: The Case of Ukraine. TEM J. 2020, 507-514. [CrossRef]

28. GUS-Główny Urząd Statystyczny. Populacja Cudzoziemców w Polsce w Czasie COVID-19, 2020b. Available online: https:/ / stat.gov.pl/statystyki-eksperymentalne/kapital-ludzki/zapotrzebowanie-rynku-pracy-na-zawody-z-systemuszkolnictwa-zawodowego,1,1.html (accessed on 14 June 2021).

29. Bourdieu, P. Symbolic Power. Crit. Anthropol. 1979, 4, 77-85. [CrossRef]

30. Wahlbeck, Ö.; Fortelius, S. The Utilisation of Migrant Capital to Access the Labour Market: The Case of Swedish Migrants in Helsinki. Soc. Incl. 2019, 7, 181-189. [CrossRef]

31. Jaeeun, K. Migration-Facilitating Capital: A Bourdieusian Theory of International Migration. Sociol. Theory 2018, 36, 62-288.

32. Al-Youbi, A.O.; Al-Hayani, A.; Rizwan, A.; Choudhry, H. Implications of COVID-19 on the Labor Market of Saudi Arabia: The Role of Universities for a Sustainable Workforce. Sustainability 2020, 12, 7090. [CrossRef]

33. Garip, F. Social capital and migration: How do similar resources lead to divergent outcomes? Demography 2008, 45, 591-617. [CrossRef] [PubMed]

34. Isański, J. Migracje i Transfery Kapitału Społecznego (Migrations and Transfers of Social Capital); Wydawnictwo Naukowe UAM: Poznań, Poland, 2015.

35. Bieniecki, M.; Pawlak, M. Strategie Przetrwania: Adaptacja Ukraińskich Migrantów Zarobkowych do Polskiej Rzeczywistości Instytucjonalnej (Survival Strategies: Adaptation of Ukrainian Labor Migrants to the Polish Institutional Reality); Instytut Spraw Publicznych: Warsaw, Poland, 2009; Available online: https://www.isp.org.pl/uploads/drive/oldfiles/podsumowanieprojektu.pdf (accessed on 31 March 2021).

36. Budyta-Budzyńska, M. Strategie Adaptacyjne Polaków w Czasie Islandzkiego Kryzysu Finansowego 2008 -2010 (Adaptation Strategies of Poles during the Icelandic Financial Crisis 2008-2010); CWR Working Paper 2013, 66/124; Ośrodek Badań nad Migracjami Uniwersytetu Warszawskiego: Warsaw, Poland, 2013.

37. Łukasiewicz, K. "Integracja" po Polsku: Strategie adaptacyjne uchodźców czeczeńskich w Polsce ("Integration" in Polish Style: Adaptation strategies of Chechen refugees in Poland). Stud. Migr. Przegląd Pol. 2011, 2, 201-219. 
38. Gerring, J. Qualitative Methods. Annu. Rev. Polit. Sci. 2017, 20, 15-36. [CrossRef]

39. MRPiT-Ministerstwo Rozwoju, Pracy i Technologii. Informacje o Zatrudnieniu Cudzoziemców w Polsce 2020 (Information on the Employment of Foreigners in Poland 2020). Available online: https://psz.praca.gov.pl/web/urzad-pracy/-/8180234informacje-o-zatrudnieniu-cudzoziemcow-w-polsce (accessed on 4 February 2021).

40. GUS-Główny Urząd Statystyczny. Wpływ Epidemii COVID-19 na Wybrane Elementy Rynku Pracy w Polsce w Trzecim Kwartale 2020 Roku (The Impact of the COVID-19 Epidemic on Selected Elements of the Labor Market in Poland in the Third Quarter of 2020). 2020. Available online: https://stat.gov.pl/obszary-tematyczne/rynek-pracy/popyt-na-prace/wplyw-epidemii-covid19-na-wybrane-elementy-rynku-pracy-w-polsce-w-trzecim-kwartale-2020-roku,4,3.html (accessed on 21 April 2021).

41. Work Service. Migracje Zarobkowe Cudzoziemców z Ukrainy i Azji do Polski (Economic Migration of Foreigners from Ukraine and Asia to Poland). Available online: https:/ /www.workservice.com/pl/Centrum-prasowe/Raporty/Raport-Migracyjny/ Migracje-zarobkowe-cudzoziemcow-z-Ukrainy-i-Azji-do-Polski (accessed on 18 February 2021).

42. Budyta-Budzyńska, M. Integration or Assimilation? Strategies of Becoming a Member of a New Community: Case of Polish Immigrants in Iceland: Reserach Report, 2011. 2011. Available online: http://www.migracje.civitas.edu.pl/migracje/index.php/ en/ (accessed on 24 April 2021).

43. Roseland, N.J. COVID-19's Impact on the Labor Market Forced a New "Normal" on the U.S. Workforce, Affecting Nearly Every Worker in the U.S. Available online: https://www.prnewswire.com/news-releases/covid-19s-impact-on-the-labormarket-forced-a-new-normal-on-the-us-workforce-affecting-nearly-every-worker-in-the-us-301068526.html (accessed on 25 February 2021).

44. Sumner, A.; Hoy, C.; Ortiz-Juares, E. Estimates of the Impact of COVID-19 on Global Poverty; WIDER Working Paper 2020/43; UNU-WIDER, United Nations University: Shibuya City, Tokyo, 2020. 